\title{
Peranan Perpustakaan Perguruan Tinggi Dalam Mencegah Penyebaran Covid 19
}

\author{
Muhammad Rasyid Ridlo ${ }^{1 *}$; Kerisman Halawa ${ }^{2}$; Sarah Imelda Putri Harefa ${ }^{3}$; \\ Yoandini Saputri ${ }^{4}$ \\ ${ }^{1,4}$ Fakultas Ilmu Budaya, Universitas Sumatera Utara \\ ${ }^{2,3}$ Fakultas Ekonomi dan Ilmu Sosial, Universitas Sari Mutiara Indonesia \\ **Korespondensi: rasyidridlo@usu.ac.id
}

\begin{abstract}
The development of COVID 19 has become a major problem for the unitary state of the Republic of Indonesia and even throughout the world. The impact is not only on the economic, social, religious, political sectors of the State even in the world of education, and is one of them is a university library. This study aims to determine the role of higher education libraries in Indonesia in the form of preventing the spread of COVID 19. The method used in this research is the study of literature. The results obtained by researchers are that eight tertiary educational libraries in Indonesia have implemented COVID prevention. The library consists of the IPB, Diponegoro University, ITB, UI, Malang University, Brawijaya University, Gadjah Mada University. This study concludes that there are 11 roles of higher education libraries in implementing COVID prevention and the most important role is that librarians are involved in the COVID cluster team 19.
\end{abstract}

Keywords: Role of higher education library; social distancing; COVID 19

\begin{abstract}
Abstrak
Perkembangan covid 19 ini telah menjadi masalah besar bagi negara kesatuan Republik Indonesia dan bahkan di seluruh dunia. Dampak bukan hanya pada sektor ekonomi, sosial, agama, politik Negara bahkan dalam dunia pendidikan dan adalah salah satunya adalah perpustakaan perguruan tinggi. Penelitian ini bertujuan untuk mengetahui peranan perpustakaan perguruan tinggi di Indonesia dalam bentuk pencegahan penyebaran covid 19 . Metode yang digunakan dalam penelitian ini adalah studi literatur. Hasil yang didapatkan peneliti adalah terdapat delapan perpustakaan perguruan tinggi di Indonesia yang sudah menerapkan pencegahan penyebaran covid. Perpustakaan tersebut terdiri dari Perpustakaan IPB, Universitas Diponegoro, ITB, Universitas Malang, Universitas Brawijaya, Universitas Gadjah Mada. Kesimpulan dari penelitian ini adalah terdapat 11 peranan perpustakaan perguruan tinggi dalam menerapkan pencegahan covid dan yang peranan yang terpenting adalah pustakwan dilibatkan dalam tim gugus covid 19.
\end{abstract}

Kata kunci: Peranan perpustakaan perguruan tinggi; sosial distancing; covid 19

\section{PENDAHULUAN}

Perkembangan covid 19 membuat resah seluruh masyarakat dunia khususnya Negara Indonesia. Masalah besar yang menjankit setiap manusia tidak dapat berinteraksi satu dengan yang lain. Hubungan kerabat, organisasi, pertemuan dibatasi demi mencegah penyebaran covid 19 berbagai upaya telah dilakukan oleh pemerintah dan yang paling menjadi garda terdepan nya adalah tenaga medis para dokter, relawan covid 19 telah berupaya mengatasi dan mencari solusi supaya covid 19 ini dapat menemukan atau penangkal virus corona. Dampak covid 19 ini tidak hanya berakibat pada sektor ekonomi, sosial, agama, pariwisata dan kultur juga berdampak pada dunia pendidikan juga.

Semenjak wadah covid 19 ini semakin hari semakin memburuk, maka setiap perguruan tinggi dan sekolah dimana pun di liburkan sesuai dengan amanah dari memdikbud. Pembelajaran dilakukan secara daring atau belajar daring/online. Masyarakat harus stay home belajar dirumah aja, kerja dirumah aja. Memang dengan kehadiran wabah covid 19 ini benar-benar membawa perubahan yang signifikan mencolok dalam kehidupan masyarakat. Lalu bagaimana dengan perpustakaan perguruan tinggi yang berfungsi sebagai pusat informasi dalam menyikapi wabah covid 19 ini?

Perpustakaan perguruan tinggi adalah perpustakaan yang diselenggarakan oleh perguruan tinggi dalam menunjang tri darma perguruan tinggi yaitu pendidikan, pembelajaran dan pengabdian masyarakat. Perpustakaan diperguruan tinggi mempunyai peran penting dalam menyikapi covid 19. 
Ada banyak perpustakaan menerapkan himbauan sosial distancing. Salah satunya adalah perpustakaan harvard ditutup karena coranavirus (covid-19). Kebijakan yang dilakukan oleh perpustakaan Harvard tidak menjadi hambatan bagi pengguna atau mahasiswa dalam berkunjung ke perpustakaan untuk belajar atau meneliti. Perpustakaan harvard memberikan kemudahan kepada seluruh mahasiswa dalam mengakses informasi. Cara nya adalah Mencari bantuan langsung dari staf kami? Anggota staf perpustakaan tersedia melalui obrolan selama jam perpustakaan diposting. Untuk menemukan jawaban atas pertanyaan umum dan mengajukan pertanyaan Anda sendiri, gunakan Tanya Pustakawan. Staf pengajar dan staf pengajar dapat memeriksa panduan kami tentang Mengajar di Kelas Virtual dengan Perpustakaan Harvard . Siswa dan peneliti dapat melihat Sumber Belajar Jarak Jauh kami . Pada saat ini, beberapa penerbit membuat konten mereka tersedia secara bebas, pelajari lebih lanjut dalam panduan kami untuk COVID-19 Sumber Daya Akses Terbuka, ("Coronavirus (COVID-19) | Harvard Library," n.d.)

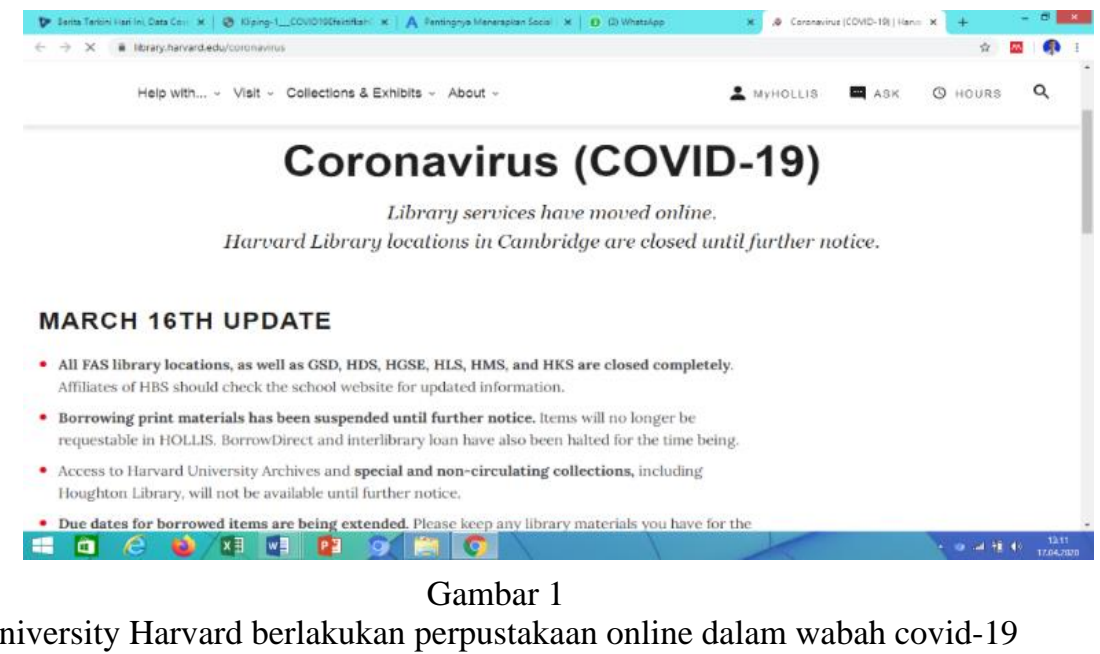

Namun, bukan hanya Perpustakaan Harvard saja yang menerapkan perpustakaan online atau sosial distancing. Di Indonesia juga ada juga perpustakaan perguruan tinggi yang menerapkan himbauan dan menutup perpustakaan menjadi perpustakaan online. Tujuan perpustakaan ditutup dan harus online supaya terhindar dari coronavirus (covid-19).

Bahaya covid 19 sangat berbahaya bagi kehidupan manusia. Memang covid 19 masuk diindonesia karena tertular lewat organ tubuh manusia. Tapi, tidak di sangka-sangka ternyata Indonesia menjadi sangat berbahaya ketimbang coronavirus (covid-19). Menghindari dari penyebaran covid ini pemerintaha dan tenaga medis berusaha mencari solusi supaya tidak bertambah banyak. Solusi yang dihimbau adalah sesuai dengan arahan dan rekomendasi dari WHO dan juga arahan Presiden Ri mengatakan bahwa seluruh masyarakat diwajibkan memakai masker saat berpergian, kerja dan keluar rumah demi penanganan covid-19 ("Imbauan Terbaru Presiden Jokowi Terkait Covid 19, Yang Keluar Rumah Wajib Pakai Masker - Halaman 3 - Tribun Manado," n.d.).

Pemerintah juga menegaskan bahwa untuk mematuhi kebijakan sosial distancing guna menghadapi pandemi covid-19. Social distancing merupakan salah satu langkah pencegahan dan pengendalian infeksi virus Corona dengan menganjurkan orang sehat untuk membatasi kunjungan ke tempat ramai dan kontak langsung dengan orang lain. Kini, istilah social distancing sudah diganti dengan physical distancing oleh pemerintah ("Pentingnya Menerapkan Social Distancing Demi Mencegah COVID-19 - Alodokter," n.d.). 
Tadwin: Jurnal Ilmu Perpustakaan dan Informasi, Vol 1 (1) 2020, Halaman: 58-73

Copyright (02020

Available Online at: http://jurnal.radenfatah.ac.id/index.php/tadwin

Ketika menerapkan social distancing, seseorang tidak diperkenankan untuk berjabat tangan serta menjaga jarak setidaknya 1 meter saat berinteraksi dengan orang lain, terutama dengan orang yang sedang sakit atau berisiko tinggi menderita COVID-19. Selain itu, ada beberapa contoh penerapan social distancing yang umum dilakukan, yaitu:

- Bekerja dari rumah (work from home)

- Belajar di rumah secara online bagi siswa sekolah dan mahasiswa

- Menunda pertemuan atau acara yang dihadiri orang banyak, seperti konferensi, seminar, dan rapat, atau melakukannya secara online lewat konferensi video atau teleconference

- Tidak mengunjungi orang yang sedang sakit, melainkan cukup melalui telepon atau video call ("Pentingnya Menerapkan Social Distancing Demi Mencegah COVID-19 - Alodokter," n.d.).

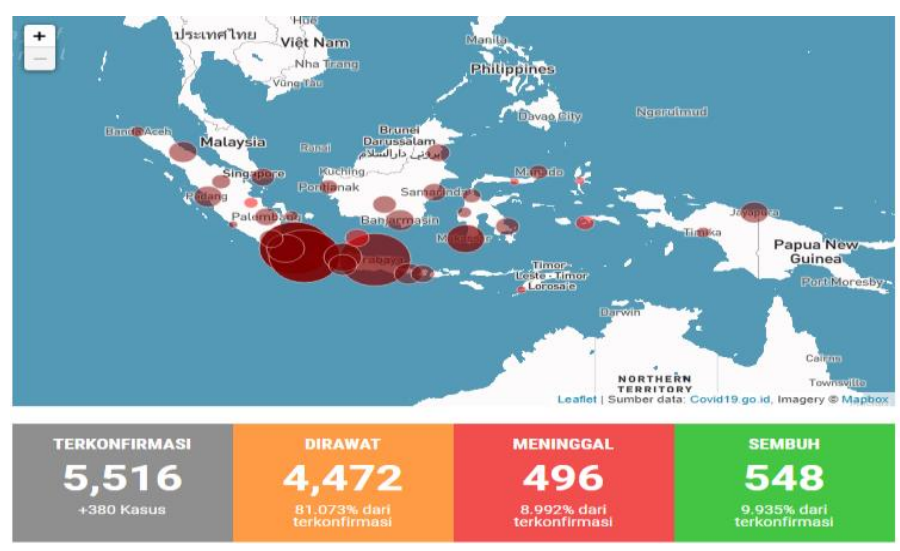

Gambar 2

Berita terkini covid 19 di Indonesia

(“Berita Terkini Hari Ini, Data Covid-19 Di Indonesia,” n.d.)

Beberapa provinsi di Indonesia soal kasus coronavirus (Covid-19) ada yang terkonfirmasi, dirawat, meninggal dan sembuh. Jadi, penerapan sosial distancing ini menjadi hal prioritas masyarakat untuk mematuhinya guna mencegah penyebaran covid-19. Di dalam artikel ini dijelaskan bagaimana peranan yang dilakukan oleh perpustakaan perguruan tinggi dalam mencegah penyebaran covid-19. Mungkin hal sebaliknya perpustakaan juga harus menjadi agen dalam penyebaran informasi yang valid dan update soal covid -19. Menghindari berita hoaks ini banyak masyarakat kita yang terpicu dan merasa takut dan bimbang soal informasi yang berita tidak benar. Jadi perpustakaan menjadi garda terdepan dalam menyebarkan informasi terkait coronavirus (covid-19) demi mencegah penyebaran covid-19. Untuk mengetahui pembahasan ini lebih jauh lagi, mari kita bahas Peranan Perpustakaan Perguruan tinggi dalam mencegah penyebaran covid-19.

\section{METODE PENELITIAN}

\section{Studi Literatur}

Metode yang digunakan dalam memperoleh data dalam penelitian ini adalah metode Studi literatur. Studi literatur ini berkenaan dengan mengumpulkan bahan pustaka, membaca, mencatat, dan mengelolah bahan penelitian. Adapun teknik yang digunakan dalam upaya pengumpulan data yaitu mencari bahan referensi yang relevan, Teori, kasus yang sesuai dengan permasalahan yang diteliti ("Metode Penelitian Studi Literatur," n.d.). Penelitian kepustakaan adalah penelitian yang dilakukan hanya berdasarkan atas karya tertulis, termasuk hasil penelitian baik yang telah maupun yang belum dipublikasikan ("PENELITIAN KEPUSTAKAAN (LIBRARY RESEARCH) - *Banjir Embun*," n.d.). Studi literatur adalah mencari referensi teori yang relefan dengan kasus atau 
Tadwin: Jurnal Ilmu Perpustakaan dan Informasi, Vol 1 (1) 2020, Halaman: 58-73

Copyright $@ 2020$

Available Online at: http://jurnal.radenfatah.ac.id/index.php/tadwin

permasalahan yang ditemukan. Bahan referensi yang relevan dengan permasalahan yang dikaji adalah:

a. Coronavirus (Covid 19)

b. Awal mula masuk ke Indonesia Covid 19

c. Sosial distancing

d. Peranan perpustakaan perguruan tinggi

Referensi ini di peroleh dari berbagai sumber yaitu dari Jurnal, Artikel, Situs-situs internet. Studi literatur ini juga termasuk dalam pengumpulan data pendukung dari permasalahan yang dikaji. Tujuannya untuk memperkuat dasar dan teori dari perumusan masalah.

\section{Pengumpulan Data}

Ada pun data yang butuhkan dalam penyelesaian penelitian ini adalah perpustakaan perguruan tinggi yang berkontribusi dalam pencegahan penyebaran covid 19 .

Tabel 1

Nama-Nama perpustakaan perguruan tinggi yang mencegah penyebaran covid 19

\begin{tabular}{cll}
\hline No & \multicolumn{1}{c}{ Nama daerah/Provinsi } & \multicolumn{1}{c}{ Perpustakaan } \\
\hline 1 & Jawa Barat & Perpustakaan IPB \\
2 & Jawa Tengah & Perpustakaan Universitas Diponegoro \\
3 & Jawa Barat & Perpustakaan ITB \\
4 & Jakarta & Perpustakaan UI \\
5 & Jawa Timur & Perpustakaan Universitas Malang \\
6 & Jawa Timur & Perpustakaan Universitas Brawijaya \\
7 & Daerah Istimewa Yogyakarta & Perpustakaan Gadjah Mada \\
\hline
\end{tabular}

Tabel diatas penulis gunakan dalam memperkuat perumusan masalah terkait dengan peranan perpustakaan perguruan tinggi dalam pencegahan penyebaran covid 19. Data ini diperoleh dari hasil pencarian situs-situs internet dan laman website perpustakaan perguruan tinggi. Jadi data tabel ini yang akan diteliti dan dijelaskan dalam pembahan mengenai peranan perpustakaan perguruan tinggi dalam pencegahan penyebaran covid 19.

\section{HASIL DAN PEMBAHASAN}

\section{A. Asal Mula Covid-19 Masuk di Indonesia}

Dilansir dari artikel News detik.com yang ditulis oleh Niken Widya Yunita bahwa Virus corona atau Covid-19 pertama kali ditemukan di Wuhan, China pada akhir 2019 lalu. Penyebaran virus yang belum ditemukan penawarnya itu hingga kini tak terkendali. Sudah 200 lebih negara di dunia melaporkan adanya kasus terpapar virus corona. Di Indonesia kasus ini pertama kali ditemukan pada dua warga Depok, Jawa Barat awal Maret lalu. Data hingga Sabtu, 28 Maret 2020 jumlah warga yang dinyatakan positif terkena virus corona mencapai 1.155 dan 102 di antaranya meninggal dunia (Gungwu, 1996) ("Penyebab, Asal Mula, dan Pencegahan Virus Corona di Indonesia," n.d.).

Selain itu, juga dikutip dari artikel Tagar.id untuk Indonesia Tiga Fakta Penyebaran Virus Corona di Indonesia yaitu ketika warga Indonesia kembali ke tanah air dan sudah terinfeksi virus corona. Kedua pasien ini diketahui merupakan warga asal Depok yang dinamakan kasus 1 (seorang perempuan berusia 31 tahun) dan kasus 2 (perempuan berusia 64 tahun yang merupakan ibu kandung kasus pertama).

Kronologi munculnya virus Corona di Indonesia berawal saat kasus 1 bertemu WNA asal Jepang yang menetap di Malaysia. Diketahui mereka melakukan kontak yang cukup dekat atau close contact sehingga mengakibatkan WNI berusia 31 tahun itu tertular Covid-19. Kemudian 
kasus 2 terinfeksi virus Corona saat sedang merawat anaknya (kasus 1) yang sedang sakit. Keduanya merupakan warga asal Depok, Jawa Barat. Dua hari kemudian tepatnya tanggal 16 Februari 2020, kedua pasien ini melakukan pemeriksaan di salah satu rumah sakit yang ada di Depok. Saat itu keduanya hanya diminta untuk melakukan rawat jalan saja. Hingga 26 Februari 2020, kondisinya tak kunjung membaik dan akhirnya meminta untuk rawat inap. Pasalnya, keduanya merasa batuk yang diderita tak kunjung reda.

Pada tanggal 28 Februari 2020, terdapat informasi yang datang ke Indonesia bahwa WNA asal Jepang positif mengidap virus Corona saat kembali ke Malaysia.Kemudian, pemerintah mulai menelusuri aktivitas WNA asal Jepang itu. Siapa saja yang ditemuinya sampai ditemukan kasus lainnya yang terkait dengan pasien 1 ("Tiga Fakta Penyebaran Virus Corona di Indonesia | Tagar," n.d.).

\section{B. Perkembangan Covid-19 di Indonesia}

Perkembangan covid-19 di Indonesia membuat pemerintah harus mencari solusi dan cara mengatasi penyebaran covid-19 agar tidak bertambah banyak. Berbagai upaya yang telah dilakukan dan hingga memberikan himbauan kepada masyarakat untuk melakukan pembatasan sosial atau sosial distancing. Himbauan ini juga merupakan rekomendasi dari badan kesehatan WHO demi mencegah penyebaran covid-19 kepada manusia yang satu dengan manusia yang lain. Data terakhir terkait perkembangan covid -19 di Indonesia yaitu Data Covid-19 di Indonesia sebagai berikut:

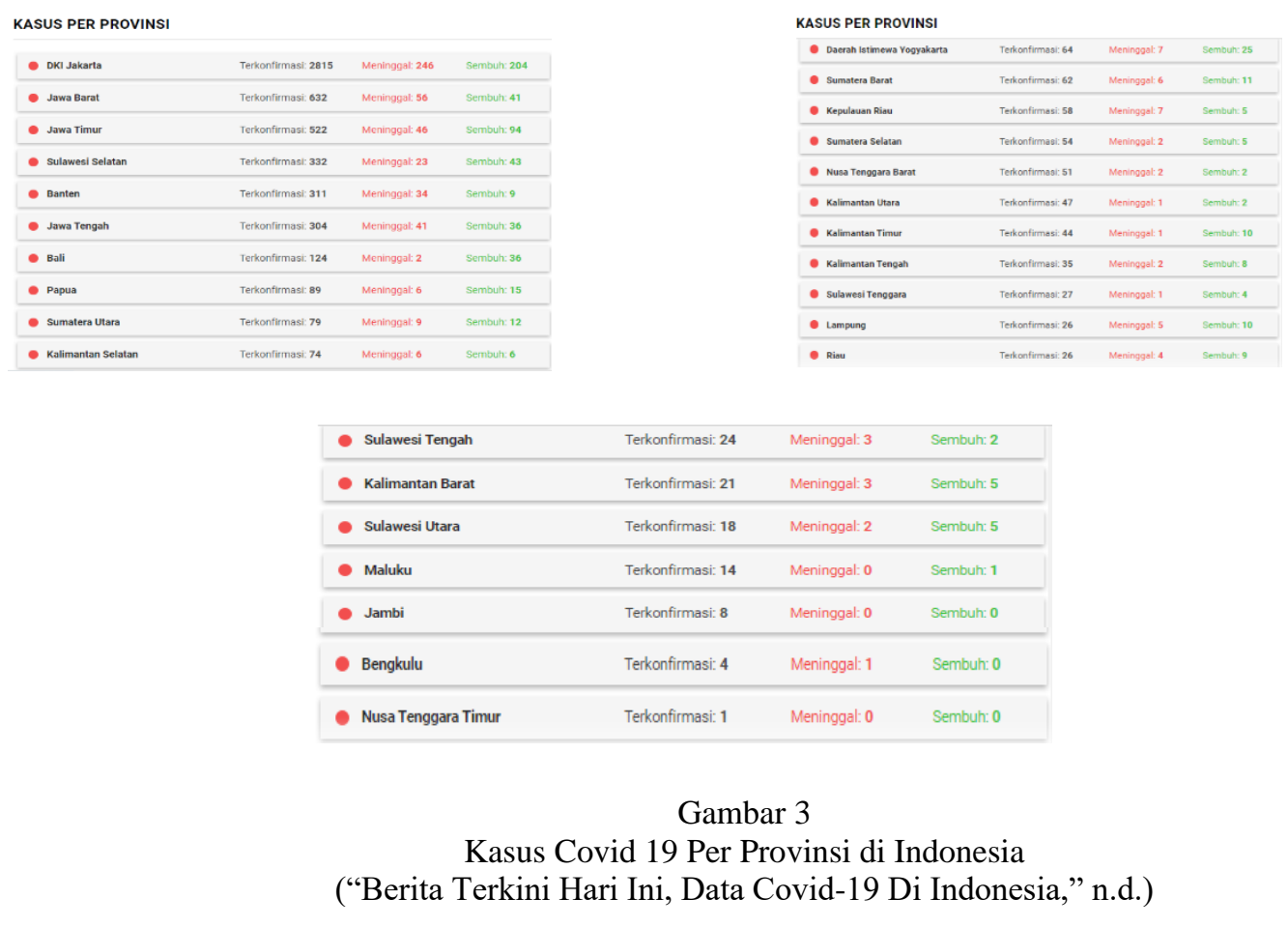

\section{Peranan Perpustakaan Perguruan Tinggi Dalam Mencegah Penyebaran Covid 19}

Menghadapi wabah Coronavirus (covid-19) ini membuat seluruh manusia merasa resah dan khawatir akan penyebarannya. Informasi ada yang jelas dan ada juga yang hoaks sehingga pikiran masyarakat merasa panik dan ketakutan terkait wabah penyakit baru ini. Perpustakaan sebagai wadah atau organisasi yang memberikan layanan informasi kepada civitas akademika dan masyrakat juga harus berkontribusi dalam mengangani pencegahan dan penyebaran covid-19. Dinamika perkembangan wabah ini membuat perpustakaan perguruan tinggi harus berkecimpung dalam dunia kesehatan. Selain perpustakaan perguruan tinggi akses informasinya bersifat fisik, menyediakan ruangan belajar bagi pemustaka dan user. Namun, wabah ini menyebabkan semua sekolah, perguruan tinggi, perpustakaan baik Nasional, Umum, Sekolah, Khusus dan perguruan 
tinggi di tutup sementara. Tentu juga akan berdampak kepada siswa dan mahasiswa yang menempuh dunia pendidikan. Apalagi dalam perguruan tinggi mahasiswa akhir semester terakhir ingin menyelesaikan studi/skripsinya juga akan terbengkalai oleh wabah covid-19, sehingga perpustakaan perguruan tinggi harus menerapkan perpustakaan perguruan tinggi online/daring. Akses informasi tetap terbuka lewat online.

Mengingat pembelajaran online, Perpustakaan perguruan tinggi pun berlakukan perpustakaan secara online. Pencarian informasi tidak secara fisik lagi melainkan virtual secara online. Salah satunya adalah Perpustakaan Harvard. Perpustakaan Harvard berlakukan perpustakaan Online demi mencegah penyebaran coronavirus (Covid-19). Perpustakaan Harvard juga berlakukan sosial distancing bagi civitas akademik public. Perpustakaan ini dalam menjawab pertanyaan dari pemakai dapat dilakuakan dengan membuka website, obrolan, konsultasi online dan tanya pustakawan online. Melalui penerapan sosial distancing maka perpustakaan perguruan tinggi telah berkontribusi dalam mencegah penyebaran coronavirus (Covid-19) telah manusia yang satu ke manusia yang lain.

Berikut adalah daftar perpustakaan perguruan tinggi yang menerapkan social distancing:

Tabel 2

Nama-Nama perpustakaan perguruan tinggi yang mencegah penyebaran covid-19

\begin{tabular}{cll}
\hline No & \multicolumn{1}{c}{ Nama daerah/Provinsi } & \multicolumn{1}{c}{ Perpustakaan } \\
\hline 1 & Jawa Barat & Perpustakaan IPB \\
2 & Jawa Tengah & Perpustakaan Universitas Diponegoro \\
3 & Jawa Barat & Perpustakaan ITB \\
4 & Jakarta & Perpustakaan UI \\
5 & Jawa Timur & Perpustakaan Universitas Malang \\
6 & Jawa Timur & Perpustakaan Universitas Brawijaya \\
7 & Daerah Istimewa Yogyakarta & Perpustakaan Gadjah Mada \\
\hline
\end{tabular}

Pembahasan lebih lanjut dari data di atas akan dijelaskan di bawah ini.

\section{Perpustakaan IPB}

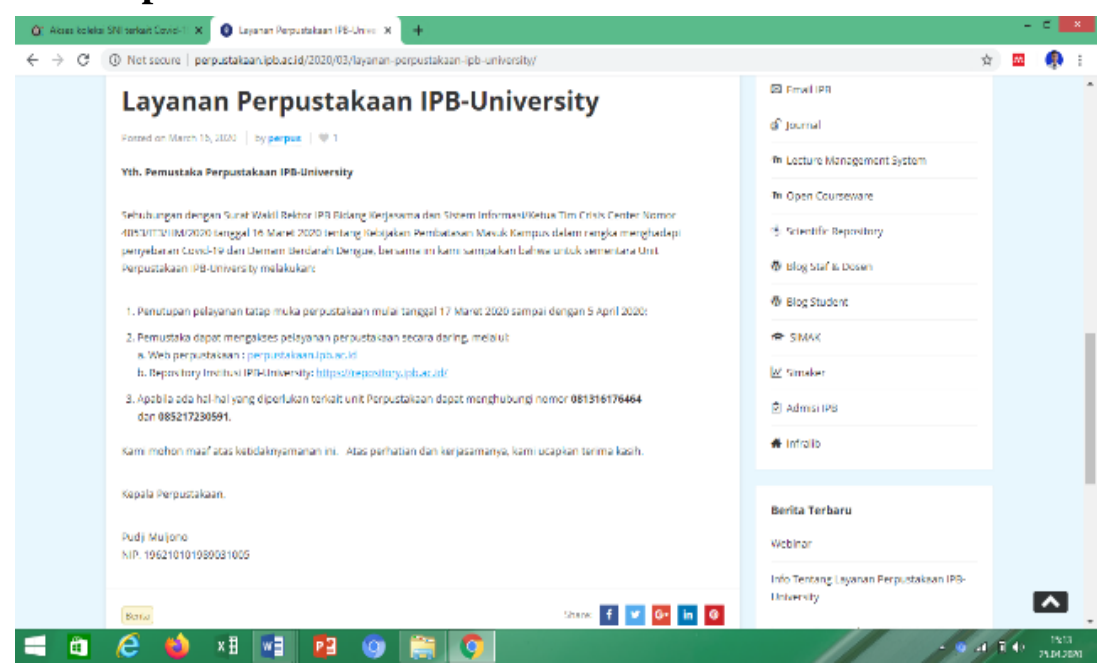

Perpustakaan IPB

(“Layanan Perpustakaan IPB-University - Perpustakaan IPB,” n.d.)

Perpustakaan IPB adalah salah satu perpustakan yang menerapkan perpustakaan Online dengan upaya pencegahan dan penyebaran covid-19. Penutupan pelayanan tatap muka perpustakaan mulai tanggal 17 Maret 2020 sampai dengan 5 April 2020; Pemustaka dapat mengakses pelayanan perpustakaan secara daring, melalui: Web perpustakaan 
:perpustakaan.ipb.ac.id, Repository Institusi IPB-University: https://repository.ipb.ac.id/, layanan pertanyan dapat disampaikan melalui media sosail perpustakaan IPB.

\section{Perpustakaan Universitas Diponegoro}

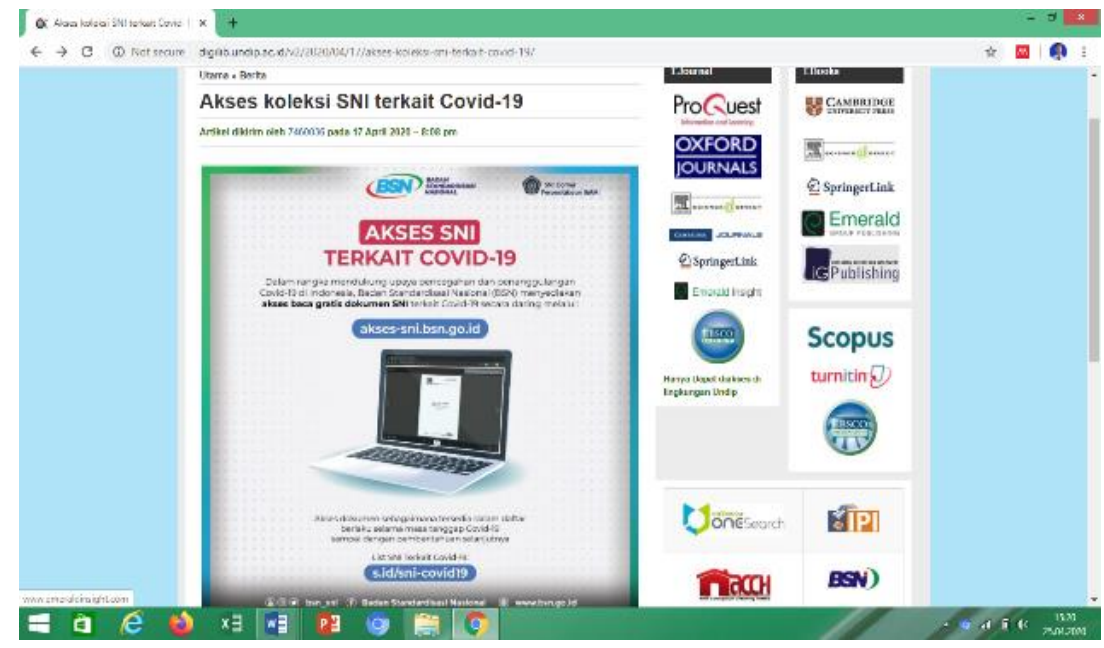

Gambar 6

Perpustakaan Universitas Diponegoro

(“Akses koleksi SNI terkait Covid-19 | Perpustakaan Universitas Diponegoro,” n.d.)

Perpustakaan Universitas Diponegoro merupakan perpustakaan yang menerapkan juga perpustakan secara online dengan upaya pencegahan dan penyebaran covid-19 dikalangan perguruan tinggi dan masyarakat sekitar. Badan standarnisasi nasional memberikan akses informasi secara gratis secara online melalui https://akses-sni.bsn.go.id/.

\section{Perpustakaan Institut Teknik Bandung}

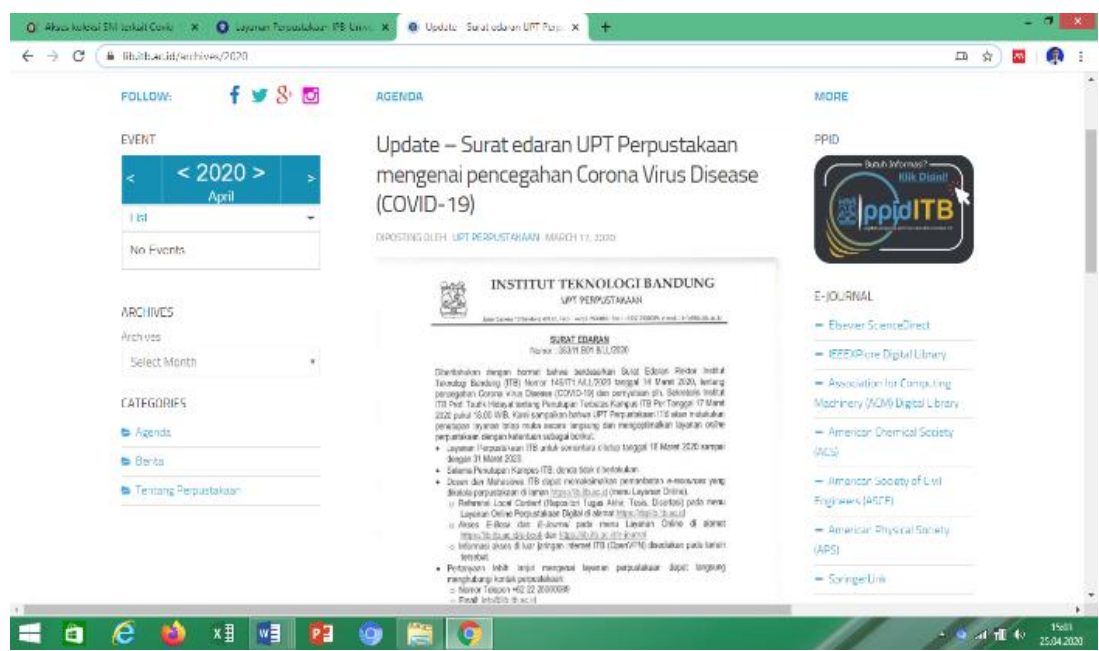

Perpustakaan ITB

(“Update - Surat edaran UPT Perpustakaan mengenai pencegahan Corona Virus Disease (COVID-19) - Perpustakaan ITB," n.d.)

Dari keterangan di atas bahwa perpustakaan ITB mempunyai peran dalam pencegahan penyebaran covid-19 dikalangan perguruan tingi. Upaya yang dilakukan adalah perpustakaan ITB dari offline menjadi online. Salah bentuk layanan yang dilakukan adalah dosen dan mahasiswa memanfaatkan layanan e-resources yang ada dilaman perpustakaan secara gratis, 
akses e-book dan akses e-jurnal. Kemudian perpustakaan ITB menerima pertanyaan dari civitas akademika dengan melalui Via telepon, Email, dan media sosial perpustakaan ITB.

\section{Perpustakaan UI}

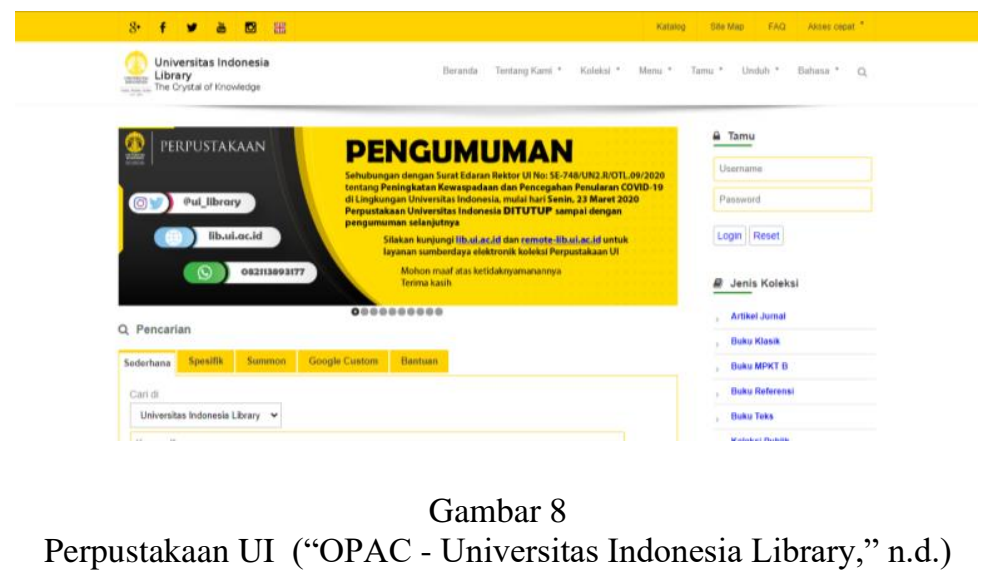

Perpustakaan UI adalah perpustakaan yang telah menerapkan perpustakaan online. Fasilitas perpustakaan kampus UI ditutup untuk umum hingga pemberitahuan lebih lanjut untuk menjaga keamanan kampus dan komunitas kami dan menghentikan penyebaran COVID-19. Staf dan pengajar UI dapat mempersiapkan diri dengan mengatur akses di luar kampus ke komputer kerja. Ikuti daftar periksa ini untuk bekerja di luar kampus .

a. Semua pengguna dengan HawkID dapat mengakses sumber daya elektronik berikut: buku elektronik, artikel online, streaming video, dan gambar elektronik. Mungkin perlu mengikuti petunjuk ini untuk membuat tautan berfungsi dari luar kampus .

b. Pinjaman antar perpustakaan dipengaruhi oleh penutupan perpustakaan dan upaya lain untuk mengurangi virus COVID-19. Pengiriman fisik buku / barang melalui Pinjaman Antar Perpustakaan dapat ditunda atau dibatalkan. Pengiriman elektronik dapat diganti. Jika Anda memiliki pertanyaan, silakan hubungi penghubung perpustakaan Anda, yang dapat membantu Anda mendapatkan akses ke item yang Anda butuhkan dalam situasi yang berubah dengan cepat ini.

c. Untuk konsultasi singkat, gunakan obrolan online Perpustakaan di http://www.lib.uiowa.edu/contact/chat, yang dikelola mulai pukul 9:00 hingga 17:00 Senin - Jumat.

d. Untuk bantuan penelitian yang kompleks, hubungi atau kirim email ke perpustakaan kampus yang sesuai (lihat daftar di atas). Anda juga dapat mengirim email langsung ke penghubung perpustakaan yang bekerja dengan bidang studi akademik Anda.

Tujuannya adalah dalam upaya pencegahan dan penyebaran coronavirus (Covid-19) dikalangan perguruan tinggi. Prioritas kesehatan, keselamatan dan kesejahteraan seluruh civitas akademika. 
Tadwin: Jurnal Ilmu Perpustakaan dan Informasi, Vol 1 (1) 2020, Halaman: 58-73

Copyright (C2020

Available Online at: http://jurnal.radenfatah.ac.id/index.php/tadwin

\section{Perpustakaan Universitas Malang}

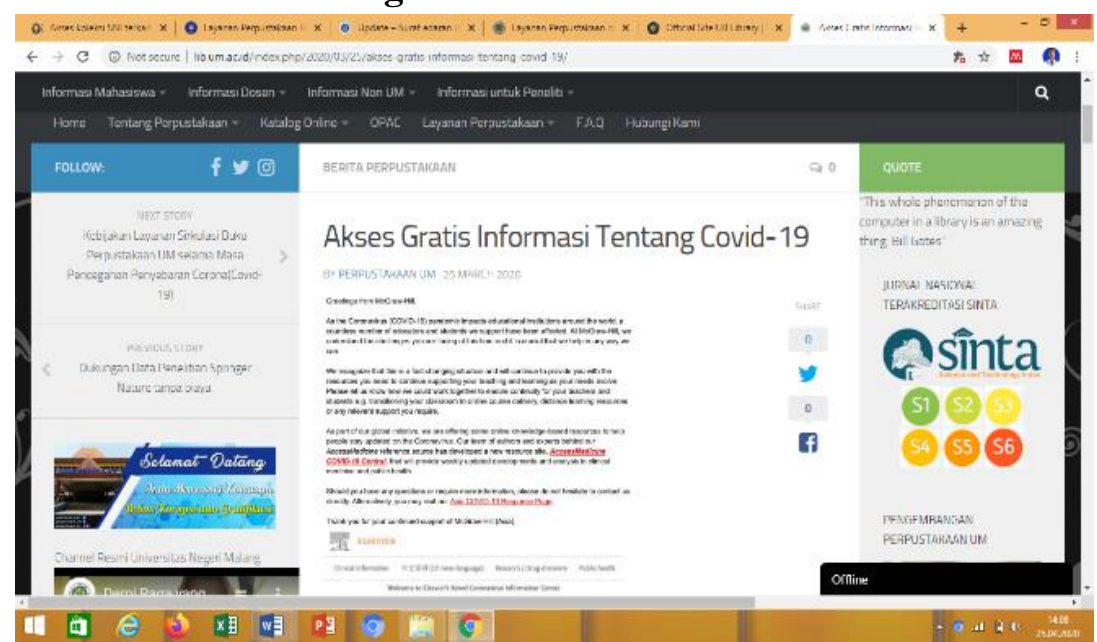

Gambar 9

Perpustakaan universitas Malang (“Akses Gratis Informasi Tentang Covid-19 - UPT Perpustakaan Universitas Negeri Malang," n.d.)

Dari keterangan diatas bahwa perpustakaan Universitas Malang mengambil peran dalam pencegahan penyebaran Covid-19 kepada seluruh civitas akademika dan masyarakat dengan cara memberlakukan akses informasi secara gratis terkait Covid-19 dengan mengunjungi alamat web

a. Elsevier's memberikan akses gratis informasi seputar novel coronavirus (SARS-CoV-2) dan COVID-19, Untuk mengakses informasi tersebut silakan membuka tautan ini: https://www.elsevier.com/connect/coronavirus-information-center

b. Wiley memberikan akses gratis informasi seputar Covid-19. mengakses informasi tersebut silakan membuka tautan ini:https://novel-coronavirus.onlinelibrary.wiley.com/

c. McGraw-Hill memberikan akses gratis informasi seputar Covid-19. Untuk mengakses informasi tersebutsilakan membuka tautan ini:

https://www.accessmedicinenetwork.com/

\section{Perpustakaan Universitas Brawijaya}

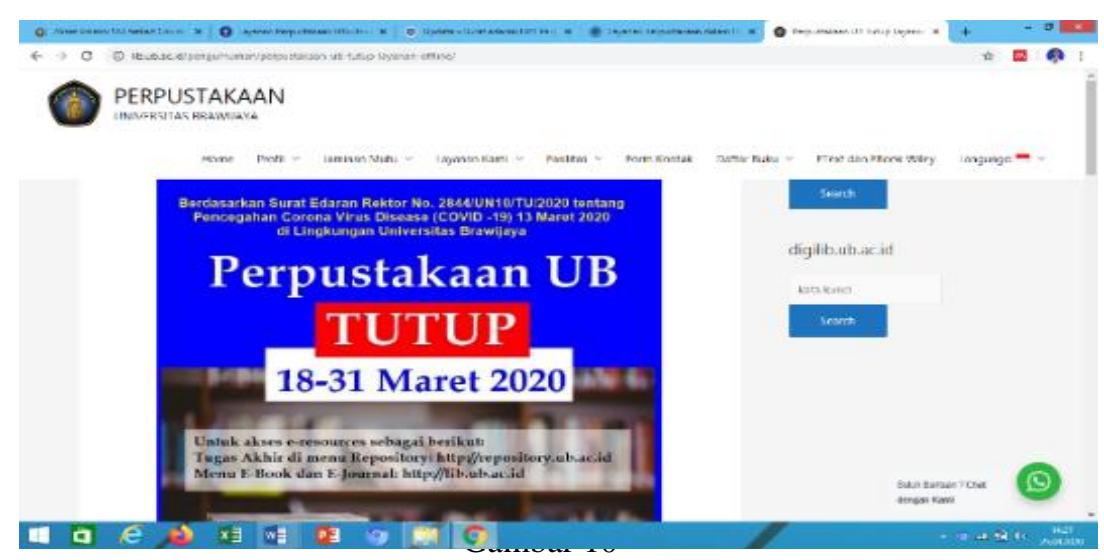

Perpustakaan Uiniversitas Brawijaya ("Perpustakaan UB Tutup Layanan OFFLINE | PERPUSTAKAAN," n.d.)

Perpustakaan Universitas Brawijaya juga mengambil peran dalam upaya pencegahan dan penyebaran Covid-19 dalam lingkungan Perguruan tinggi. Bentuk upaya yang dilakukan adalah 
perpustakaan ditutup secara offline. Perpustakaan UB tidak off melainkan membuka perpustakaan secara online. Ketentuan nya adalah perpustakaan UB membantu civitas akademika dengan :

- Pemustaka didorong untuk menggunakan e-resources yang ada di http://lib.ub.ac.id

- Tugas Akhir di menu REPOSITORY http://respository.ub.ac.id

- Menu E-Book dan E-Journal htpp://lib.ub.ac.id

- Apabila mengalami kesulitan, bisa bertanya atau meminta bantuan untuk download artikel/ebook/tugas akhir melalui WA Pustakawan atau Direct Message library@ub.ac.id

- Petugas Perpustakaan yang bertugas harus menggunakan masker dan sarung tangan latek.

- Perpustakaan menggunakan termogun untuk memantau suhu badan staff.

- Kegiatan berkerumun di perpustakaan seperti workshop, seminar, bedah buku, kunjungan ke Perpustakaan UB ditunda dijadwal ulang.

- Perpustakaan menyediakan layanan online via whats app dan socil media.

- Penyediaan hand sanitizer di tempat-tempat strategis dan penyediaan hand soap di wastafel toilet perpustakaan dan staff dihimbau untuk mencuci tangan secara teratur.

- Perpustakaan harus membersihkan tempat yang banyak disentuh pengunjunga seperti pegangan tangga, handel pintu, meja dan kursi dengan disinfektan.

- Pengembalian buku ditiadakan dan segala denda selama masa tersebut ditiadakan.

\section{Perpustakaan Gadjah Mada}

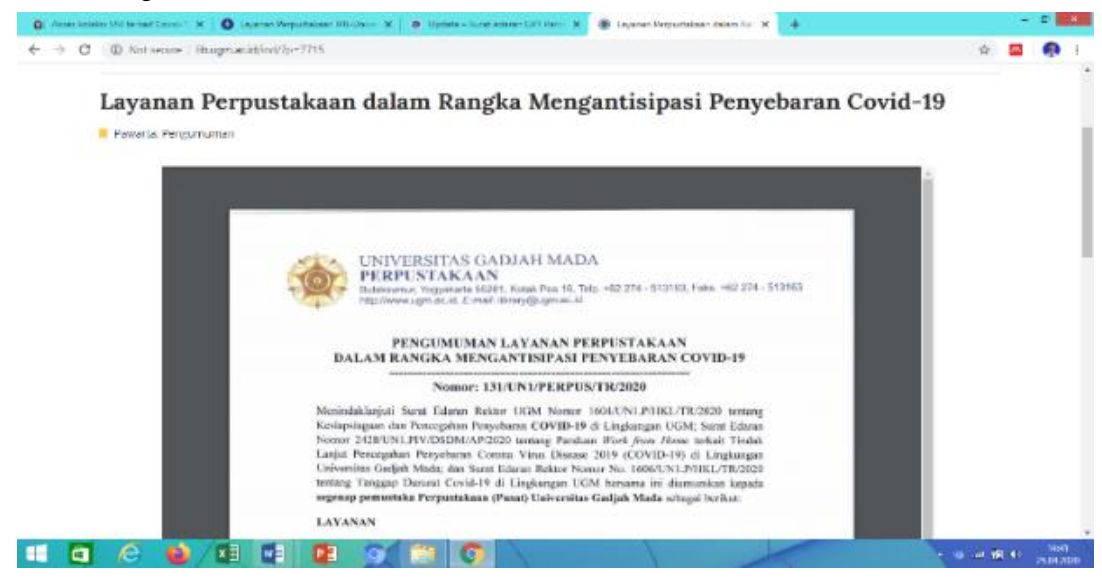

Perpustakaan UGM (“Layanan Perpustakaan dalam Rangka Mengantisipasi Penyebaran Covid-19 Perpustakaan,” n.d.)

Layanan perpustakaan UGM dalam melakukan pencegahan penyebaran covid-19 adalah perpustakaan UGM membuka layanan sumber belajar daring (online) melalui lib.ugm.ac.id yang dikombinasikan melalui email dan media sosial, Perpustakaan UGM menerima layanan informasi terkait layanan, ETD, pencarian infromasi artikel/jurnal/buku/publikasi dapat disampaikan ke : layanan.lib@ugm.ac.id, layanan informasi terkait akses internet, unggah, akses databse disampaikan ke : Basisdata.lib@ugm.ac.id, layanan Via telepon, layanan Medos perpustakaan, dan perpustakaan UGM menerapkan himbauan dari pemeritah dan kesehatan soal sosial distancing, wajib memakai masker, mencuci tangan dengan sabun dan hand sanitizer dan selalu menjaga kebersihandna pola hidup sehat.

Dari tabel di atas dapat diketahui bahwa ternyata perpustakaan perguruan tinggi di Indonesia berkontribusi dalam mencegah penyebaran covid-19. Di sisi lain perpustakaan perguruan 
tinggi tidak off tetapi tetap melayani civitas akademika walapun dalam keadaan covid. Karena perpustakaan perrguruan tinggi mempunyai metode yang jitu dalam memenuhi kebutuhan pemakai. Perpustakaan dilakukan secara online, menggunakan media elektronik seperti obrolan tanya jawab, dalam lain-lain. Jadi, perpustakaan perguruan tinggi tetap mempertahankan misinya dalam mencerdaskan kehidupan anak bangsa.

Peranan perpustakaan dalam mencegah penyebaran Covid-19 adalah:

a. Perpustakaan tidak offline tapi online atau daring.

b. Perpustakaan membuat aturan teknis terkait pencegahan covid-19 dilingkungan internal. Staff perpustakaan jika datang ke ruang kerja. Maka diwajibkan membersihkan setiap fasilitas dalam perpustakaan baik itu papan komputer, saklar lampu, handel pintu dengan desinfektan 2 kali dalam sehari.

c. Perpustakaan perguruan tinggi perlu melakukan sosialisasi dengan materi terkait coronavirus (Covid-19) atau materi tentang kesehatan yang dilakukan secara Online melalui aplikasi video conference seperti Zoom.

d. Perpustakaan dalam upaya pencegahan covid-19 memberikan layanan akses gratis informasi seputar coronavirus (Covid-19) dilaman situs tertentu.

e. Penghindaran dari wabah covid-19 perpustakaan menunda kegiatan seminar, workshop, bedah buku atau studi banding, semua dilaksanakan secara online.

f. Perpustakaan perguruan wajib menyediakan hand sanitizer disetiap pintu masuk dan keluar dan staff dihimbau untuk mencuci tangan dengan sabun yang teratur demi pencegahan covid19.

g. Perpustakaan perguruan menerapkan himbauan dari pemerintah dan kesehatan dengan memakai masker dan mematuhi peraturan sosial distancing.

h. Perpustakaan perguruan dalam mencerdaskan kehidupan bangsa memberikan layanan informasi secara gratis melalui e-book, e-journal, buku dan publikasi secara online.

i. Perpustakaan perguruan tinggi menerima pertanyaan dari pemustaka melalui via telepon, via WhatsApp, dan media sosial perpustakaan yang bersangkutan.

j. Perpustakaan perguruan tinggi dalam upaya pencegahan penyebaran covid-19 harus menjadi penyebar informasi yang aktual, menjadi konsultan, siap melayani.

Perpustakaan perguruan tinggi juga dalam menjadi gugus depan pembantu pencegahan penyebaran covid 19. Perpustakaan menyebarkan berupa SMS boom kepada via telepon masyarakat sama seperti sms dari Gugus depan penangangan covid 19 dengan isi berupa himbauan dari tentang pencegahan covid 19 .

\section{Bahaya Covid Jika Perpustakaan Perguruan Tinggi Tidak Menerapkan Social Distancing}

Dilansir dari artikel Kemkes.go.id bahawa dampak dari coronavirus (Covid-19) ini adalah:

a. Dampaknya terlalu besar membawa kematian yang banyak, coronavirus ini harus diwaspadai karena sumber penularannya beragam dan perkembangan belum jelas.

b. Berbeda dengan MERS dan SARS yang juga disebabkan oleh corona virus, dimana kedua penyakit ini mempunyai dampak yang sangat besar baik dalam sektor kesehatan maupun sosial ekonomi dunia. 
Tadwin: Jurnal Ilmu Perpustakaan dan Informasi, Vol 1 (1) 2020, Halaman: 58-73

Copyright $@ 2020$

Available Online at: http://jurnal.radenfatah.ac.id/index.php/tadwin

Sejalan dengan pernyataan diatas juga. Seperti yang dikutip dari Artikel liputan6.com tentang 5 Alasan Virus Corona Covid-19 Berbahaya, Tetap Waspada menurut dr. Erni Juwita Nelwan, MD, FACP, FINASIM yaitu:

a. Penularan lewat droplet

Erni menjelaskan, penularan virus Corona melalui percikan/tetasan (droplet) yang ukurannya berbagai macam. Ada droplet besar dan kecil. Droplet besar ini akan memindahkan virus lewat tangan. Seperti ketika bersin, batuk, yang kemudian orang sakit tersebut memegang benda-benda di sekitarnya.

b. Agresif

Virus Corona merupakan virus agresif dengan tingkat penularan yang tinggi. Meski SARS dinyatakan virus mematikan, perbedannya dengan virus corona ada pada kecepatan penularan virus. Virus Corona menular lebih cepat dari SARS.

c. Penularan lewat interaksi

Dilansir dari Liputan6, penularan virus Corona juga bisa lewat berkumpul atau beraktivitas di tengah kerumunan. Sebab, virus Corona dapat menempel secara kasat mata pada pakaian dan benda yang dibawa orang lain.

d. Gejala ringan

COVID-19 memiliki gejala ringan seperti gangguan pernapasan atau penyakit flu biasa sehingga agak sulit untuk mengetahui gejalanya tanpa melakukan pemeriksaan atau tes di rumah sakit khusus. Adapun beberapa gejalanya, antara lain batuk kering, demam, pilek, sakit tenggorokan, gangguan pernapasan, letih, serta lesu.

e. Riwayat Penyakit

Bagi orang yang memiliki riwayat penyakit tertentu, seperti diabetes dan penyakit jantung, lebih rentan terkena virus corona dan mengalami komplikasi parah ketika positif COVID-19.

Dari beberapa bahaya coronavirus (Covid-19) tidak dicegah dengan cepat akan berakibat fatal. Oleh karena itu, Bahaya covid jika perpustakaan perguruan tinggi tidak menerapkan social distancing:

a. Hilangnya eksistensi perpustakaan perguruan tinggi sebagai distribusi atau penyebar informasi

b. Penularan coronavirus (Covid-19) akan bertambah.

c. Menurunnya angka untuk berinteraksi kembali dengan normal.

d. Meningkatnya angka kematian bagi civitas akademika dan masyarakat, keluarga, kerabat dan masyarakat sekitar efek penularan.

e. Memperlambat hubungan silaturami secara kontak fisik.

f. Bahaya penyakit covid-19 ini berakibat pada sektor dunia pendidikan.

g. Memperlambat pertemuan pembelajaran tata muka atau face to face terhadap dosen pengajar dan mahasiswa.

h. Hilangnya kesadaran belajar diperpustakaan tidak seperti biasanya khususnya pemakai informasi.

i. Tidak memiliki rasa komitmen dalam mencegah penyebaran covid-19 atas himbauan pembatasan sosial/sosial distancing. 
Tadwin: Jurnal Ilmu Perpustakaan dan Informasi, Vol 1 (1) 2020, Halaman: 58-73

Copyright $@ 2020$

Available Online at: http://jurnal.radenfatah.ac.id/index.php/tadwin

j. Dan yang terakhir berakibat pada kesehatan, ekonomi yang terinfeksi dan, menghambat kinerja pemerintah dan tenaga medis dalam menangani pencegahan penyebaran coronavirus (Covid-19).

\section{E. Tantangan Dan Kendala Perpustakaan Perguruan Tinggi Dalam Mencegah Penyebaran Covid-19}

Coronavirus (Covid-19) ini yang ditandai dengan adanya penutupan sementara perpustakaan dan diberlakukan sosial distancing atau pembatas sosial yang menimbulkan sebuah tantangan besar bagi perpustakaan yang bersangkutan. Tantangan ini mau tidak mau akan menjadi tantangan dan peluang besar bagi perpustakaan perguruan tinggi untuk merubah pola perpustakaan menjadi perpustakaan online. Tantangan nya adalah pustakawan disetiap perpustakaan diperguruan tinggi harus benar-benar menguasai teknologi dan informasi. Karena dengan wabah ini perpustakan sudah menjadi perpustakaan hibrida perpustakaan tanpa tembok. Perpustakaan diperguruan tinggi juga menyediakan fasilitas teknologi dalam melayani pemakai informasi dengan nyaman dan memuaskan.

Bagi pustakawan hal ini akan menjadi peluang besar sekaligus tantangan dalam menguji penguasaan teknologi agar tetap eksis dalam melayani pemakai informasi dengan media elektronik. Tujuannya juga tidak lain dari langkah pencegah dan penyebaran covid-19. Sedankan kendala perpustakaan perguruan tinggi dalam mencegah penyebaran coronavirus (Covid-19) adalah perpustakaan diperguruan tinggi nya tidak menyediakan fasilitas teknologi yang mampu berhubungan/berinteraksi kepada civitas akademika dalam melayani dan mengakses informasi. Terutama bagi mahasiswa yang menyelesaikan studi butuh referensi yang berasal dari perpustakaan.

Jika perpustakaan memiliki fasilitas website, media obrolan, media tanya jawab, bimbingan konsultasi maka akan perpustakaan akan eksis dalam melayani pemakai informasi. Jika tidak ada ataupun pustakawannya tidak paham soal teknologi tidak mungkin jasa layanan informasi bisa membantu civitas akademika. Oleh karena itu, tantangan dan kendala perpustakaan perguruan tinggi dalam mencegah covid-19 ini tergantung penyediaan fasilitas teknologi perpustakaan, pustakawan berketerampilan dibidang IT, dan pelayanan jasa informasi maka akan membantu masyarakat dan civitas akademika dalam mencegah penyebaran coronavirus (Covid-19).

\section{F. Solusi Perpustakaan Perguruan Tinggi Dalam Mengatasi Penyebaran Covid-19}

Dilansir dari Artikel liputan6.com bahwa solusi pencegahan dan penyebaran covid-19 adalah Patuhi himbauan yang diberikan pemerintah seperti tetap berada di rumah atau stay home, menjaga jarak (physical distancing), dan rajin mencuci tangan. Himbauan ini harus dilaksanakan demi keluarga, kerabat, sahabat, pekerjaan kita, Perkuliahan kita, sekolah kita, ekonomi kita, kesehatan kita, Prihatin dengan Tenaga medis yang merawat kita, bangsa dan Negara Kita Indonesia. Begitu juga dengan perpustakaan perguruan tinggi. Upaya yang dilakukan dalam pencegahan ini adalah:

a. Membuka perpustakaan Online

b. Membuka kelas diskusi online antara pustakawan dengan mahasiswa (pemakai Informasi).

c. Membuka ruang Obrolan online

d. Membuka tanya jawab pertanyaan kepada pustakawan secara online

e. Membuka informasi seputar coronavirus (Covid-19) 
Tadwin: Jurnal Ilmu Perpustakaan dan Informasi, Vol 1 (1) 2020, Halaman: 58-73

Copyright $@ 2020$

Available Online at: http://jurnal.radenfatah.ac.id/index.php/tadwin

f. Mengadakan video conference melalui media elektronik atau lewat aplikasi seperti Zoom, Hangout, group WhatsApp, Cludx

g. Menerapkan himbauan dari pemerintah mengenai pembatasan sosial atau sosial distancing, jaga jarak 1-2, stay Home, memakai masker saat berpergian dan rajin mencuci tangan, memakai hand sanitizier. Tujuanya adalah demi pencegahan penyebaran covid-19 kepada manusia yang satu dengan manusia lain.

h. Membuat flyer berupa berita, himbauan dari pemerintah terkait coronavirus (Covid-19) secara online dengan meletakan nya dihalaman website berita perpustakaan.

\section{SIMPULAN}

Berdasarkan hasil penelitian di atas disimpulkan bahwa peranan perpustakaan perguruan tinggi dalam mencegah penyebaran penyebaran Covid-19 sangat berkontribusi sekali seperti perpustakaan UI, USU,IPB, ITB, UB,UM, dan perpustakaan telah berperan dan telah mensosialisasikan materi coronavirus kepada civitas akademik dan memberikan pelayanan yang memuaskan kepada pemustaka agar misi dan visi perpustakaan perguruan tinggi tetap terwujud. Peran perpustakaan perguruan tinggi dalam pencegahan penyebaran covid-19 adalah:

a. Perpustakaan tidak offline tapi online atau daring.

b. Perpustakaan membuat aturan teknis terkait pencegahan covid-19 dilingkungan internal. Staff perpustakaan jika datang ke ruang kerja. Maka diwajibkan membersihkan setiap fasilitas dalam perpustakaan baik itu papan komputer, saklar lampu, handel pintu dengan desinfektan 2 kali dalam sehari.

c. Perpustakaan perguruan tinggi perlu melakukan sosialisasi dengan materi terkait coronavirus (Covid-19) atau materi tentang kesehatan yang dilakukan secara Online melalui aplikasi video conference seperti Zoom.

d. Perpustakaan dalam upaya pencegahan covid-19 memberikan layanan akses gratis informasi seputar coronavirus (Covid-19) dilaman situs tertentu.

e. Penghindaran dari wabah covid-19 perpustakaan menunda kegiatan seminar, workshop, bedah buku atau studi banding, semua dilaksanakan secara online.

f. Perpustakaan perguruan wajib menyediakan hand sanitizer disetiap pintu masuk dan keluar dan staff dihimbau untuk mencuci tangan dengan sabun yang teratur demi pencegahan covid19.

g. Perpustakaan perguruan menerapkan himbauan dari pemerintah dan kesehatan dengan memakai masker dan mematuhi peraturan sosial distancing, jaga jarak 1-2 meter, stay home, memakai masker saat berpergian, rajin mencuci tangan, dan memakai hand sanitizier. Tujuannya adalah demi pencegahan penyebaran covid-19 kepada manusia yang satu dengan manusia lain.

h. Membuat flyer berupa berita, himbauan dari pemerintah terkait coronavirus (Covid-19) secara online dengan meletakan nya dihalaman website berita perpustakaan.

i. Perpustakaan perguruan dalam mencerdaskan kehidupan bangsa memberikan layanan informasi secara gratis melalui e-book, e-journal, buku dan publikasi secara online.

j. Perpustakaan perguruan tinggi menerima pertanyaan dari pemustaka melalui via telepon, via WhatsApp, dan media sosial perpustakaan yang bersangkutan.

k. Perpustakaan perguruan tinggi dalam upaya pencegahan penyebaran covid-19 harus menjadi penyebar informasi yang aktual, menjadi konsultan, siap melayani.

1. Perpustakaan perguruan tinggi juga dalam menjadi gugus depan pembantu pencegahan penyebaran covid 19. Perpustakaan menyebarkan berupa SMS boom kepada via telepon 
masyarakat sama seperti sms dari Gugus depan penangangan covid 19 dengan isi berupa himbauan dari tentang pencegahan covid 19.

Jadi, akses informasi tidak menjadi halangan bagi civitas akademik dalam memperoleh informasi secara gratis dan penerapan ini sudah menjadi bentuk dari sosial distancing learning virtual, belajar dirumah aja, demi pencegahan penyebaran coronavirus (Covid-19) kepada manusia satu dengan manusia lainnya. Hindari kerumuman, patuhi sosial distancing atau jaga jarak minimal 1-2 meter, memakai masker, rajin mencuci tangan dengan sabun dan jaga pola hidup sehat agar tetap sehat dan terhindar dari coronavirus (Covid-19).

\section{DAFTAR PUSTAKA}

Akses Gratis Informasi Tentang Covid-19 - UPT Perpustakaan Universitas Negeri Malang. (n.d.). Retrieved June 18, 2020, from http://lib.um.ac.id/index.php/2020/03/25/aksesgratis-informasi-tentang-covid-19/

Akses koleksi SNI terkait Covid-19 | Perpustakaan Universitas Diponegoro. (n.d.). Retrieved June 1, 2020, from http://digilib.undip.ac.id/v2/2020/04/17/akses-koleksi-sni-terkaitcovid-19/

Berita Terkini Hari Ini, Data Covid-19 Di Indonesia. (n.d.). Retrieved June 12, 2020, from https://www.kompas.com/covid-19

Coronavirus (COVID-19) | Harvard Library. (n.d.). Retrieved June 1, 2020, from https://library.harvard.edu/coronavirus

Gungwu, W. (1996). Sojourning: The Chinese Experience in Southeast Asia. Australia: Asia Publication Series.

Imbauan Terbaru Presiden Jokowi Terkait Covid 19, Yang Keluar Rumah Wajib Pakai Masker - Halaman 3 - Tribun Manado. (n.d.). Retrieved June 8, 2020, from https://manado.tribunnews.com/2020/04/06/imbauan-terbaru-presiden-jokowi-terkaitcovid-19-yang-keluar-rumah-wajib-pakai-masker?page $=3$

Layanan Perpustakaan dalam Rangka Mengantisipasi Penyebaran Covid-19 - Perpustakaan. (n.d.). Retrieved June 1, 2020, from http://lib.ugm.ac.id/ind/?p=7715

Layanan Perpustakaan IPB-University - Perpustakaan IPB. (n.d.). Retrieved June 19, 2020, from http://perpustakaan.ipb.ac.id/2020/03/layanan-perpustakaan-ipb-university/

Metode Penelitian Studi Literatur. (n.d.). Retrieved April 18, 2020, from http://digilib.its.ac.id/public/ITS-Undergraduate-5121-4201100038-bab3.pdf

OPAC - Universitas Indonesia Library. (n.d.). Retrieved June 21, 2020, from http://lib.ui.ac.id/home

PENELITIAN KEPUSTAKAAN (LIBRARY RESEARCH) - *Banjir Embun*. (n.d.). Retrieved June 14, 2020, from https://www.banjirembun.com/2012/04/penelitiankepustakaan.html

Pentingnya Menerapkan Social Distancing Demi Mencegah COVID-19 - Alodokter. (n.d.). Retrieved July 1, 2020, from https://www.alodokter.com/pentingnya-menerapkan-socialdistancing-demi-mencegah-covid-19

Penyebab, Asal Mula, dan Pencegahan Virus Corona di Indonesia. (n.d.). Retrieved June 1, 2020, from https://news.detik.com/berita/d-4956764/penyebab-asal-mula-danpencegahan-virus-corona-di-indonesia

Perpustakaan UB Tutup Layanan OFFLINE | PERPUSTAKAAN. (n.d.). Retrieved June 19, 2020, from https://lib.ub.ac.id/pengumuman/perpustakaan-ub-tutup-layanan-offline/ 
Tadwin: Jurnal Ilmu Perpustakaan dan Informasi, Vol 1 (1) 2020, Halaman: 58-73

Copyright $@ 2020$

Available Online at: http://jurnal.radenfatah.ac.id/index.php/tadwin

Tiga Fakta Penyebaran Virus Corona di Indonesia | Tagar. (n.d.). Retrieved June 11, 2020, from https://www.tagar.id/tiga-fakta-penyebaran-virus-corona-di-indonesia

Update - Surat edaran UPT Perpustakaan mengenai pencegahan Corona Virus Disease (COVID-19) - Perpustakaan ITB. (n.d.). Retrieved June 1, 2020, from https://lib.itb.ac.id/archives/2020 